\title{
Hayat Bilgisi Dersinde Dijital Bir Değerlendirme*
}

\author{
İrfan SÜRAL, Pınar GIRMEN**
}

Hayat Bilgisi Dersinde Dijital Bir Değerlendirme

Özet

Bu çalışmanın amacı, hayat bilgisi dersinde dijital bir değerlendirme aracı geliştirmek ve uygulama sürecini betimlemektir. Bu amaç doğrultusunda nitel ve nicel araştırma yaklaşımlarının birlikte kullanıldığı karma desenden yararlanılmıştır. Araştırmanın katılımcılarını orta sosyo-ekonomik çevreye sahip bir okulun birinci sınıfına devam eden 32 öğrenci ve bu sınıfların öğretmenleri oluşturmuştur. Araştırmanın nicel verileri; öğrencilerin oyun sürecindeki hamle sayıları, oynarken geçirdikleri süre ve elde ettikleri skorlara dayalı olarak toplanmıştır. Araştırmanın nitel boyutundaki veriler sınıf öğretmenleriyle gerçekleştirilen yarı yapılandırılmış görüşmeler aracılığıyla toplanmıştır. Araştırma bulgularına göre; geliştirilen dijital değerlendirme aracının uygulama sürecinde öğrencilerin teknoloji kulanım becerileri konusunda sorunlar yaşadıkları öte yandan aracı kullanmaktan keyif aldıkları belirlenmiştir.

Anahtar Kelimeler: İlkokul, Hayat Bilgisi, Dijital Değerlendirme

\author{
Digital Assessment in Social Studies Course
}

Abstract

The purpose of this study is to develop a digital assessment tool in social studies course and describe development and application process. The study is designed as mixed method research where both quantitative and qualitative methods are used. The participants of the study consisted of teachers and 32 students who were in the first grade of a school with a medium socio-economic environment. Quantitative data of the study were based on the number of moves of the students during the game, the time they spent while playing and the scores they achieved. The qualitative data of the study were collected through semistructured interviews. According to the results; in application process of digital assessment tool students enjoy but have some problems in using technology.

\section{Giriş}

Hayat bilgisi dersi; birey, toplum ve doğa ekseninde çocuğun temel yaşam becerilerini edinmesini hedefleyen ilkokul düzeyindeki bir derstir. Bu dersle; çocuğun doğumundan itibaren dünyayı nasıl anlamlandırdığına ilişkin yaşantıları merkeze alınarak sonraki yaşamına ilişkin bilgi, beceri ve değerlerin kazandırılması hedeflenmektedir (Kabapınar, 2012, 36). Bu bağlamda Hayat Bilgisi Dersi Öğretim Programı'nın temel amacı; yaşam becerile-

*Bu çalışma 26-28 Nisan 2018 tarihleri arasında II. Uluslararası Sınırsız Eğitim ve Araştırma Sempozyumu' nda sözlü bildiri olarak sunulmuştur.

**irfan SÜRAL, Dr. Öğr. Üyesi. Eskişehir Osmangazi Üniversitesi, Bilgisayar ve Öğretim Teknolojileri Eğitimi Bölümü, isural@gmail.com, ORCID ID orcid.org/0000-0003-2232-9483; Pınar GIRMEN, Doç. Dr. Eskişehir Osmangazi Üniversitesi, Temel Eğitim Bölümü, pgirmen@gmail.com, ORCID ID orcid.org/0000-0001-6194-8354 
İrfan SÜRAL | Pınar GIRMEN

rine sahip, kendini tanıyan, sağlıklı ve güvenli bir yaşam süren, yaşadığı toplumun değerlerini özümseyen, doğaya ve çevreye duyarlı, araştıran, üreten ve ülkesini seven bireyler yetiştirmektir (MEB, 2018). Bu temel amacın yanında öğrencilerin; problem çözme, iletişim, sorumluluk, araştırma, bilgi ve iletişim teknolojilerini kullanma, dengeli beslenme, iş birliği, sağlığını koruma gibi gerekli becerileri edinmeleri de hedeflenmektedir (MEB, 2018). Çocukların hayat bilgisi dersinde edindikleri bilgi ve becerileri kendi yaşamlarına nasıl aktardıklarının ve sosyal ilişkilerinde bu bilgi ve becerilerden nasıl yararlandıklarının belirlenmesi önemlidir. Başka bir deyişle, öğrencilerin hayat bilgisi dersi kavramlarına, beceri ve tutumlarına ne ölçüde sahip olduklarının belirlenmesi öğretim programının amacına ulaşmasının önemli bir boyutunu oluşturmaktadır. Bu belirlemenin yapılabilmesi ölçme ve değerlendirme süreçleri ile ilgilidir. Değerlendirme, eğitim ve öğretimin önemli bir parçasıdır. Eğitim programlarının başarısı, öğrencilerde beklenen bilgi, beceri ve tutumların gelişip gelişmediği, ölçme ve değerlendirme yoluyla belirlenir. Bu nedenle ölçme ve değerlendirme, eğitim öğretimi sürekli izleyerek aksaklıkları zamanında görme ve düzenleme şansı verir (Güleryüz, 2008, 277). Hayat Bilgisi Dersi Öğretim Programı, ölçme ve değerlendirme sürecinde azami çeşitlilik ve esneklik anlayışıyla hareket edilmesi gerektiğine vurgu yapmaktadır (MEB, 2018). Bu söylemden hareketle, sınıf öğretmenlerinden hayat bilgisi dersine yönelik gerek süreç ve gerekse sonuç değerlendirmede farklı yöntemleri kullanmaları beklenmektedir. Ancak ilgili araştırmaların sonuçlarına göre öğretmenlerin; özellikle sürece yönelik ölçme ve değerlendirme yaklaşımlarını kullanmada zorluklar yaşadıkları belirlenmiştir (Duban ve Küçükyılmaz, 2008; Kanatlı, 2008; Anılan, H. ve Kılıç, Z. 2010; Gömleksiz, M.N. Yıldırım, F. ve Yetkiner, A. 2011; Güneş ve Baki, 2011; Kaya, Balay ve Göçen, 2012; Kilmen ve Kösterelioğlu, 2017). Sürece yönelik ölçme ve değerlendirme yaklaşımlarının kullanımında yaşanan sorunların; çok zaman alması, sınıfların kalabalık olması, öğretmenlerin konu hakkında yeterince bilgi sahibi olmamaları ve buna dayalı olarak edindikleri algılar gibi noktalarda toplandığı görülmektedir. Yaşanan sorunlar göz önüne alındığında hayat bilgisi dersi ölçme ve değerlendirme sürecinde azami çeşitlilik anlayışının uygulamaya dönüştürülemediği söylenebilir. Bu bağlamda hayat bilgisi dersi ölçme ve değerlendirme sürecinde kullanılabilecek dijital bir değerlendirme aracının geliştirilip uygulama sürecinin betimlenmesi önemli görülebilir.

Dijital değerlendirme araçları, değerlendiricilerin kâğıt kalem ile değerlendirme yapmak yerine bilgisayar veya mobil cihazlar üzerinden değerlendirme yapmalarına olanak sağlayan teknolojiler olarak belirtilebilir. Dijital değerlendirme araçlarının geliştirilmesi ve uygulanmasında en yaygın kullanılan ortamlardan birisi de web ortamlarıdır. Web ortamları, teknolojinin gelişmesi ile çeşitli evrimler geçirmiş, bireyin pasif bir izleyiciden etkin bir katılımcıya dönüşmesi özellikle Web 2.0 araçları sayesinde gerçekleşmiştir. Günümüzde "dijital yerli" (Prensky, 2007) olarak adlandırılan öğrencilerin çoğu Web 2.0 teknolojilerini günlük yaşamlarında daha fazla kullanmaktadırlar. Web 2.0 teknolojileri öğrencileri kaynakları yeniden kullanmasına ve yeni bilgileri oluşturmasına teşvik etmektedir (An, 
Aworuwa, Ballard, ve Williams, 2010). Web 2.0 teknolojileri sayesinde günümüzde etkileşimi yüksek, katılımcı odaklı sistemler geliştirmek ve bunları eğitim öğretim faaliyetlerinde kullanmak olanaklı hale gelmiştir. Dijital değerlendirme araçları günümüzde ağırlıklı olarak web tabanlı etkinlikler, oyunlar, animasyonlar ile gerçekleştirilmektedir.

Dijital değerlendirme araçları web tabanlı etkinlik, oyun, bulmaca ve animasyon gibi birçok uygulama içerdiğinden dolayı öğrencilere daha yüksek düzeyde düşünme olanağı sağlayan zengin çeşitlilikte öğrenme yöntemleri sunmaktadır (Eyal, 2012). Çetinkaya ve Taş, (2016) yapmış oldukları çalışmada altıncı sınıf "Vücudumuzda Sistemler" ünitesine yönelik web tabanlı bir materyal geliştirmiş ve bu materyale 27 kazanımın her birine 3 adet sorudan oluşan dijital bir değerlendirme aracı eklemiştir. Geliştirilen materyalde, kazanımlar için sorulan sorulara verilen cevapların program tarafından analiz edilerek yanlış öğrenmelerin farkında olmaları ve bunu gidermeleri için ilgili etkinliklere yönlendirdiği belirtilmiştir. Çalışmada, öğrencilerin üst bilişsel yeteneklerini geliştirmesine yardımcı olunmasına yönelik hazırlanan materyalin ölçme değerlendirme boyutunun etkili olduğu vurgulanmıştır. Bir başka çalışmada Paliç ve Akdeniz, (2012) ortaöğretim 9. sınıf Fizik dersi "Enerji" ünitesine yönelik beyin temelli öğrenmeye dayalı web destekli öğretim materyalini değerlendirmişlerdir. Bu materyalin değerlendirme soruları bölümünün öğrenci seviyesine uygun olmadığı, daha farkındalık yaratacak soruların sorulması gerektiği önersinde bulunulmuştur. Akça, Barut, ve Önder, (2014) çalışmasında fen öğretiminde öğrencilerin uzaktan öğrenmelerini sağlayabileceği web tabanlı öğrenme ortamı tasarlamış, bu ortamın tasarımında konu anlatımları, sınavlar ve grafikler için asp tabanlı bir web ara yüzü, ders içerisindeki etkinlik ve deneyler için de flash tabanlı etkileşimli animasyonların kullanıldığı belirtilmiştir. Fen laboratuvarı olmayan, araç-gereç eksikliği nedeniyle veya tehlikeli olabilecek durumlar için fen deneylerini yapamayan öğrenciler bu web tabanlı ortamda deneylerini yapma imkânı bulacağı vurgulanmıştır. Ayrıca öğrencilere web ortamına entegre edilmiş konuyla ilgili MEB'deki kitap içeriklerini okuyup, etkinlikler yaparak ve testler ile kendilerini sınayarak konuları bir bütün halinde öğrenebilme imkanı sunulduğu ifade edilmiştir. Yapılan çalışmalar, öğrencilerin öğrenmelerini desteklemek ve gerçek yaşamda uygulama ortamı bulunmayan etkinliklerin gerçekleştirilmesini sağlamaktır. Bu amaçla, öğrencilere web tabanlı öğrenme ortamları sunulmuş ve uygulama süeçleri betimlenmiştir. Bu bağlamda bu araştırmanın amacı, hayat bilgisi dersinde dijital bir değerlendirme aracı geliştirmek ve uygulama sürecini betimlemektir. Bu amaçla, Hayat Bilgisi Dersi Öğretim Programı birinci sınıf, Sağlıklı Hayat ünitesinde yer alan "1.3.8. Sağlıklı beslenme için meyve ve sebzelerin mevsimine uygun olarak tüketilmesi gerektiğini bilir" (MEB,2015) kazanımı seçilmiş ve bu kazanıma dayalı bir dijital değerlendirme aracı geliştirilmesi hedeflenmiştir. Öğrencilerin sınıf ortamında dört mevsime ait farklı meyve ve sebzeleri aynı anda inceleme fırsatlarının bulunmayışı ve ünite kazanımlarını somutlaştırması amacıyla ilgili kazanım tercih edilmiştir. 
İrfan SÜRAL | Pınar GIRMEN

\section{Yöntem}

Araştırmada nicel ve nitel araştırma yaklaşımlarının birlikte kullanıldığı karma desenden yararlanılmıştır. Karma desen araştırmaları, araştırma problemini daha iyi anlayabilmek amacıyla nicel ve nitel yaklaşımların, yöntemlerin, kavramların veya tekniklerin bir arada kullanıldığı, araştırmanın bazı aşamalarında hem nicel hem de nitel verilerin toplandığı, analiz edildiği veya birleştirildiği çalışmalardır (Creswell, 2008; Gay, Mills ve Airasian, 2006; Johnson ve Christensen, 2008; Johnson ve Onwuegbuzie, 2004). Bu bağlamda nicel ve nitel yöntemlerin aynı çerçeve içerisinde kullanımı ile karma yöntem araştırmaları, her iki yöntemin avantajlı taraflarını kuvvetlendirmektedir (Baki ve Gökçek, 2012). Böylelikle nicel ve nitel yöntemlerin birleşimi araştırma problemini daha iyi anlamak için bu yöntemlerden herhangi birini yalnız başına kullanmaya kıyasla daha fazla avantaj sağlamaktadır.

\subsection{Katılımcılar}

Araştırmanın katılımcılarını, Eskişehir il merkezinde devlete bağlı bir ilkokulun birinci sınıflarında öğrenim gören 14 erkek ve 18 kız öğrenci olmak üzere toplam 32 öğrenci oluşturmaktadır. Katılımcıların belirlenmesinde amaçlı örnekleme türlerinden ölçüt örnekleme kullanılmıştır. Ölçüt örnekleme, önceden belirlenmiş çeşitli ölçütleri içeren bütün durumların çalışılmasını temele almaktadır (Yıldırım ve Şimşek, 2013). Araştırmada, okulun bilgisayar laboratuvarına sahip olmaması, yerleşim yerinin sosyoekonomik açıdan orta düzeyde olması ve katılımcı öğrencilerin ilgili kazanıma ilişkin ders işlemiş olmaları ölçüt olarak ele alınmıştır. Katılımcıların belirlenmesinde teknoloji kullanım becerilerinin orta düzey olması ve bilgisayar laboratuvarının okulda olmayışı araştırmanın verileri açısından önemli görülmüştür. Katılımcıların değerlendirme aracını kullanırken yaşadıkları kararsızlıkları belirlemede sürükle bırak eylemi bu bağlamda değerlendirilmiştir. Araştırmada yarı yapılandırımış görüşme yapılan kadın sınıf öğretmeni 21 yıllık, erkek sınıf öğretmeni ise 22 yıllık kıdeme sahiptir. Her iki öğretmen de daha önce dijital bir değerlendirme aracı kullanmamışlardır.

\subsection{Verilerin Toplanması}

Araştırma verileri; 2017-2018 eğitim öğretim yılının bahar dönemi Nisan ayında toplanmıştır. Dijital değerlendirme aracı, farklı sınıflara iki farklı günde uygulanmıştır. Birinci sınıfların A şubesindeki öğrenciler 18.04.2018 tarihinde 12.45- 14.42 saatleri arasında okulun toplantı odasında dizüstü bilgisayar aracılığıyla tek tek uygulama sürecine katılmışlardır. Birinci sınıfların diğer şubesinde olan öğrenciler ise 25.04.2018 tarihinde 12.5515.16 saatleri arasında A şubesi ile aynı şekilde uygulamayı tamamlamışlardır. Uygulamanın sonunda uygulamaya katılan öğrencilerin öğretmenleriyle yarı yapılandırılmış görüş- 
me gerçekleştirilmiştir. Yarı yapılandırılmış görüşme formunda dijital değerlendirmenin hayat bilgisi dersi birinci sınıfta değerlendirme aracı olarak kullanılabilirliği; kazanım, öğrencilerin gelişim özellikleri, süre, öğrencilerin teknolojik yeterlikleri açılarından irdelemeyi amaçlayan sorulardan oluşmaktadır.

\subsubsection{Dijital Değerlendirme Ortamının Geliştirilmesi}

Araştırmada meyve sebzelerin seçiminde yaygın olandan yaygın olmayana doğru bir sıra izlenmiştir. Değerlendirme aracına hangi meyve ve sebzelerin dâhil edilmesi ve ilgili meyve ve sebzelerin mevsimlere göre dağılımı için iki ziraat fakültesi öğretim üyesinden görüş alınmıştır. Araştırmada kullanılan dijital değerlendirme aracının geliştirilmesi için kullanılabilecek teknolojiler araştırılmış, hedef kitlenin yaş ve teknolojik yeterlilikleri göz önünde bulundurularak sürükle bırak teknolojisini destekleyen ve öğrencilere değerlendirme sürecini oyunlaştıran bir tasarımda karar kılınmıştır. Şekil 1' de ekran görüntüsü verilen dijital değerlendirme aracında en üstte rastgele 12 'şerli olarak ekrana gelen meyve ve sebzeler gösterilmektedir. Öğrenci her bir meyve veya sebzeyi ilgili mevsim adı altındaki siyah kutucuğa sürükle bırak yöntemi ile yerleştirmeye çalışmaktadır. Eğer yerleşim doğru olursa tebrik mesajı ile dönüt verilmekte, yanlış mevsime yerleştirilmesi durumunda ise meyve veya sebzenin hangi mevsimde olması gerektiğine dair dönüt verilmektedir.

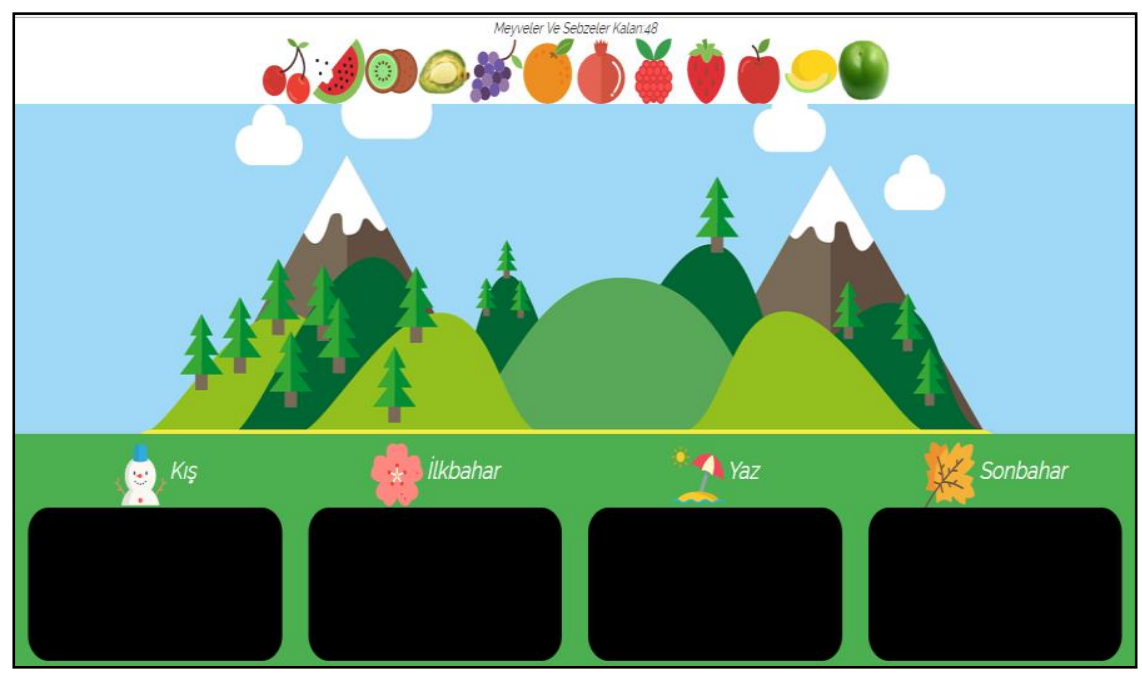

Şekil 1. Dijital Değerlendirme Aracı

Öğrencilerin uygulamayı tablet veya mobil cihazlardan gerçekleştirebilmesi ve fare kullanma becerisi olmayanlar için engel oluşturmaması amacıyla sürükle bırak özelliğini 
İrfan SÜRAL | Pınar GIRMEN

sunan JavaScript kütüphanelerinden yararlanılmıştır. Ayrıca görsel tasarım şablonu hedef yaş özelliği dikkate alınarak seçilmiştir.

\subsection{Verilerin Analizi}

Araştırmanın nitel verileri içerik analizi tekniği kullanılarak çözümlenmiştir. İçerik analizinde amaç verileri açıklayabilecek kavram ve ilişkilere ulaşmaktır (Yıldırım ve Şimşek, 2008). Ses kaydı aracılığıyla elde edilen veriler, hiçbir değişiklik yapılmadan olduğu gibi görüşme formuna yazılmış ve elde edilen veriler, temel anlamlar ve ilişkiler dikkate alınarak temalandırımıştır. Temalar araştırmacılar ve bir uzman tarafından birbirinden bağımsız bir biçimde oluşturulmuştur. Analiz sonuçları karşılaştırılmış ve yapılan kodlamalar görüş birliği ve görüş ayrılığı şeklinde kodlanmıştır. Miles ve Huberman (1994) güvenirlik formülüne göre uyum sağlanmıştır (\% 94).

Araştırmanın nicel verileri katılımcılara uygulanan dijital değerlendirme aracı kullanılarak toplanmıştır. Katılımcıların her bir meyve ve sebze seçiminde geçirdikleri süre, sürükle-bırak eyleminin başarılı/başarısız sayısı, doğru ve yanlış meyve sayısı arka planda MySQL veri tabanında toplanmış ve ardından Excel verisi olarak aktarılmıştır. Araştırmanın verileri frekans aracılığı ile grafiklerle sunulmuştur.

\section{Bulgular}

Grafik 1'e göre öğrencilerin seçilen 48 meyve ve sebzeyi mevsimine doğru yerleştirmek için yaptığı toplam hareket sayısı 1779 'dur. Öğrenciler sürükle/bırak (drag \& drop) özelliğini kullanarak gerçekleştirdikleri bu hareketlerin 243’ü başarısızlıkla sonuçlandığından toplam cevap yani sebze ve meyveyi herhangi bir mevsime başarılı yerleştirme sayısı 1536 olarak gerçekleşmiştir. Bu cevaplardan 572'si doğru iken yanlış cevap sayısı 964'tür.

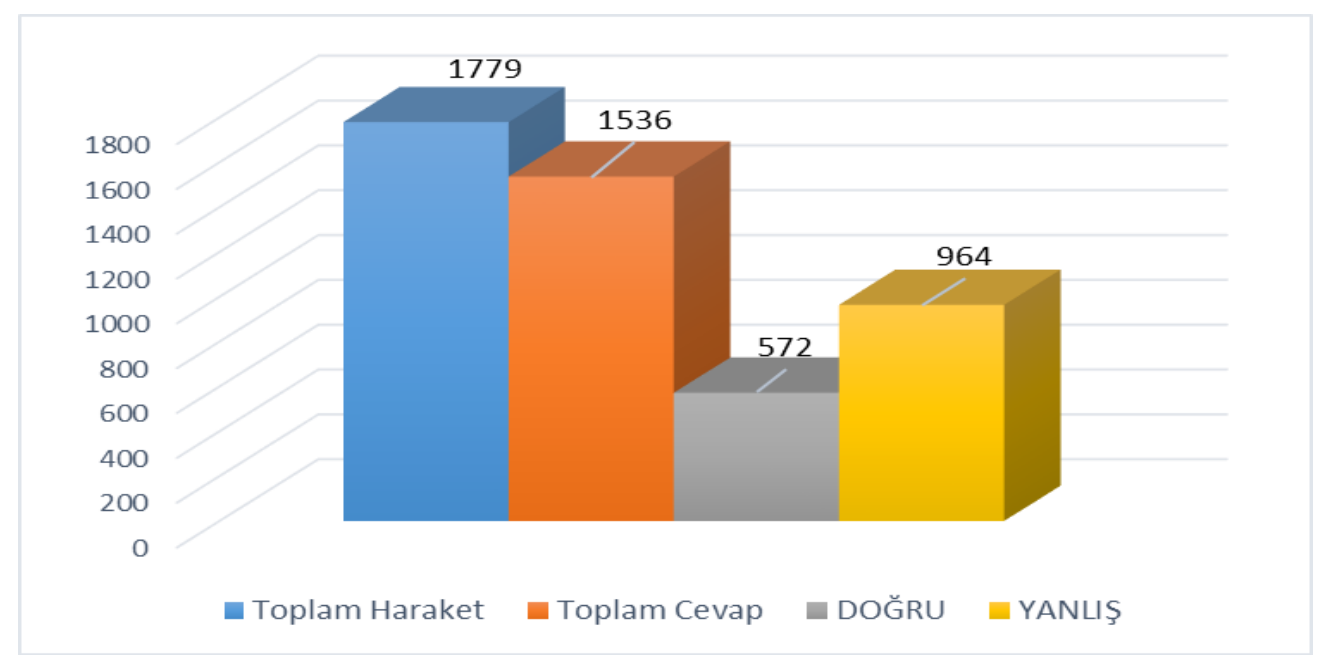


Grafik 1. Öğrencilerin Toplam Hareket, Cevap ve Doğru/Yanlış Dağılımları ( $N=32$ )

Sebze ve meyveler mevsimlerine göre gruplandırıldıktan sonra oluşturulan grafikler ve öğrencilerin seçim hareketleri aşağıda sunulmuştur. Grafik 2' de Sonbahar mevsiminde bulunan sebze ve meyvelerin öğrenciler tarafından doğru/yanlış tahmin edilme sayıları ile sürükle bırak esnasında teknik sorunlar (farenin takılması vb.), el becerisi ya da öğrencinin kararsızlığından dolayı uzun süre tıklamayı koruyamayıp tuşu serbest bırakma yani başarıSIz gerçekleşen "DRAG" hareket sayıları verilmiştir. Buna göre öğrenciler sonbahara ait sebze ve meyve grubundan en çok Enginar (13), Karnabahar (9) ve Ahududuyu (9) doğru bilmiş öte yandan en çok Böğürtlen (29), Kızılcık (27) ve Havucu (26) yanlış tahmin etmişlerdir. Bununla beraber öğrencilerin gerçekleştirdiği "DRAG" eylemine bakıldığında en çok Nar (8), Enginar (6) ve Ayva (5) sebze ve meyvesi yer almaktadır. Başka bir deyişle öğrenciler en çok Nar, Enginar ve Ayvayı mevsimlerle eşleştirirken kararsızlık yaşamışlardır.

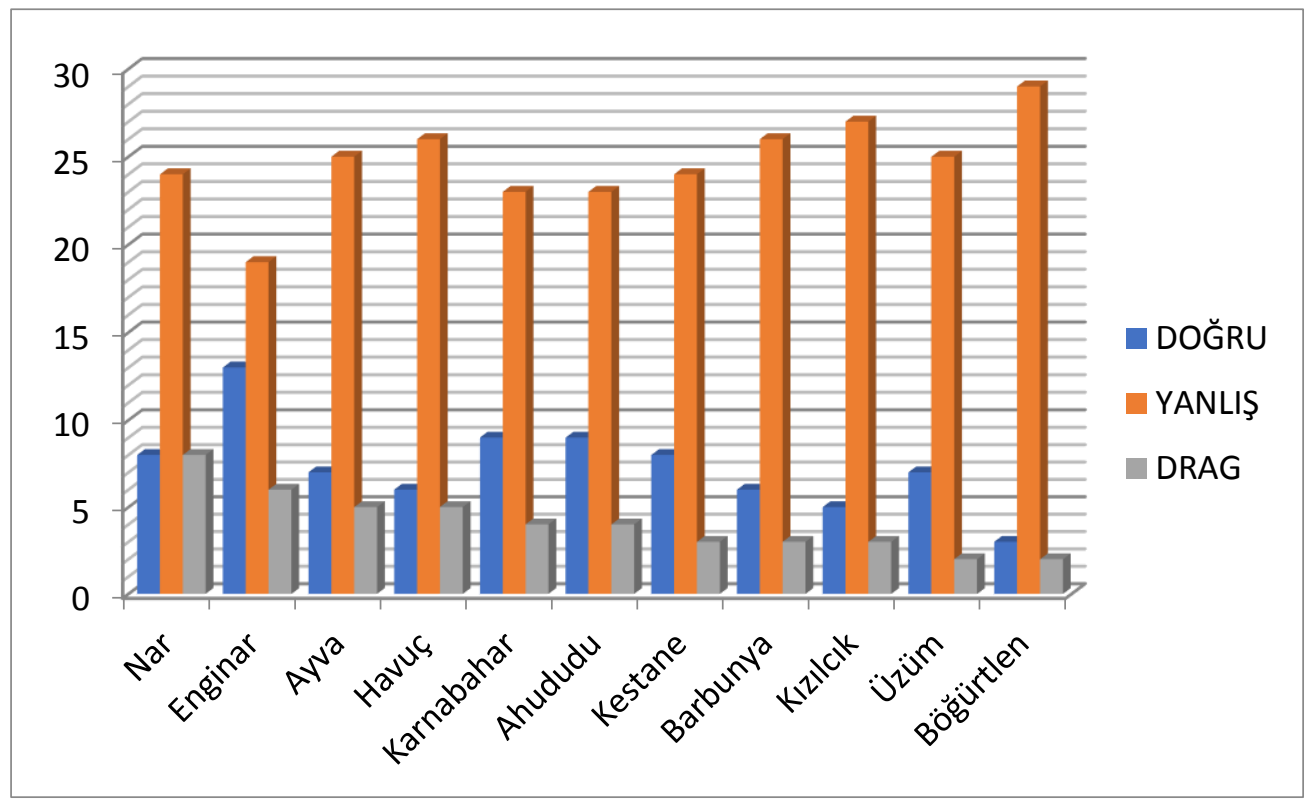

Grafik 2. Mevsimlere göre (Sonbahar) öğrencilerin meyve ve sebze seçim hareketleri

$(\mathrm{N}=32)$

Kış mevsimine ait sebze ve meyveler üzerindeki öğrenci seçim hareketlerinin verildiği Grafik 3 incelendiğinde benzer şekilde yanlış cevapların doğru cevaplardan daha fazla olduğu görülmektedir. Buna göre öğrenciler kışa ait sebze ve meyve grubundan en çok Pırasa (20), Portakal (19) ve Ispanağı (13) doğru bilmiş öte yandan en çok Muz (29), Armut 
(28) ve Lahanayı (24) yanlış tahmin etmişlerdir. "DRAG" eyleminin en çok gerçekleştiği sebze ve meyve ise Pırasa (8), Kivi (6) ve Kereviz (6) olarak gerçekleşmiştir.

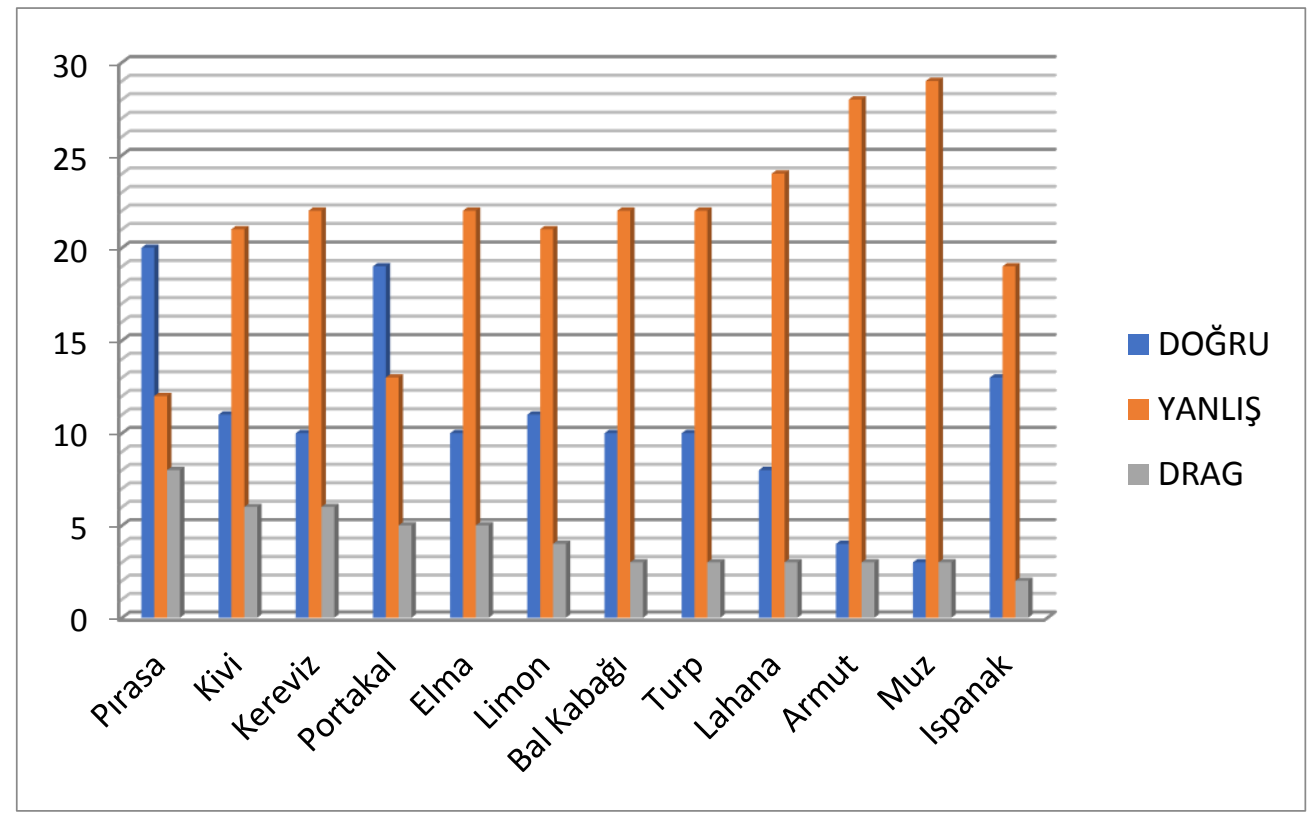

Grafik 3. Mevsimlere göre (Kış) öğrencilerin meyve ve sebze seçim hareketleri ( $N=32)$

Öğrencilerin ilkbahar mevsimindeki sebze ve meyveler için gerçekleştirdikleri seçim hareketlerinin verildiği Grafik 4 incelendiğinde en çok Roka (17), Semiz Otu (16) ve Çilek (12) doğru bilinmiş diğer yandan en çok Soğan (24), Bezelye (24) ve Can Erik (23) bilinememiştir. Sürükle bırak eyleminin tamamlanamadığı "DRAG" hareketi incelendiğinde en çok Semiz Otu (9), Can Erik (6) ve Roka (5) ön plana çıkmaktadır. 


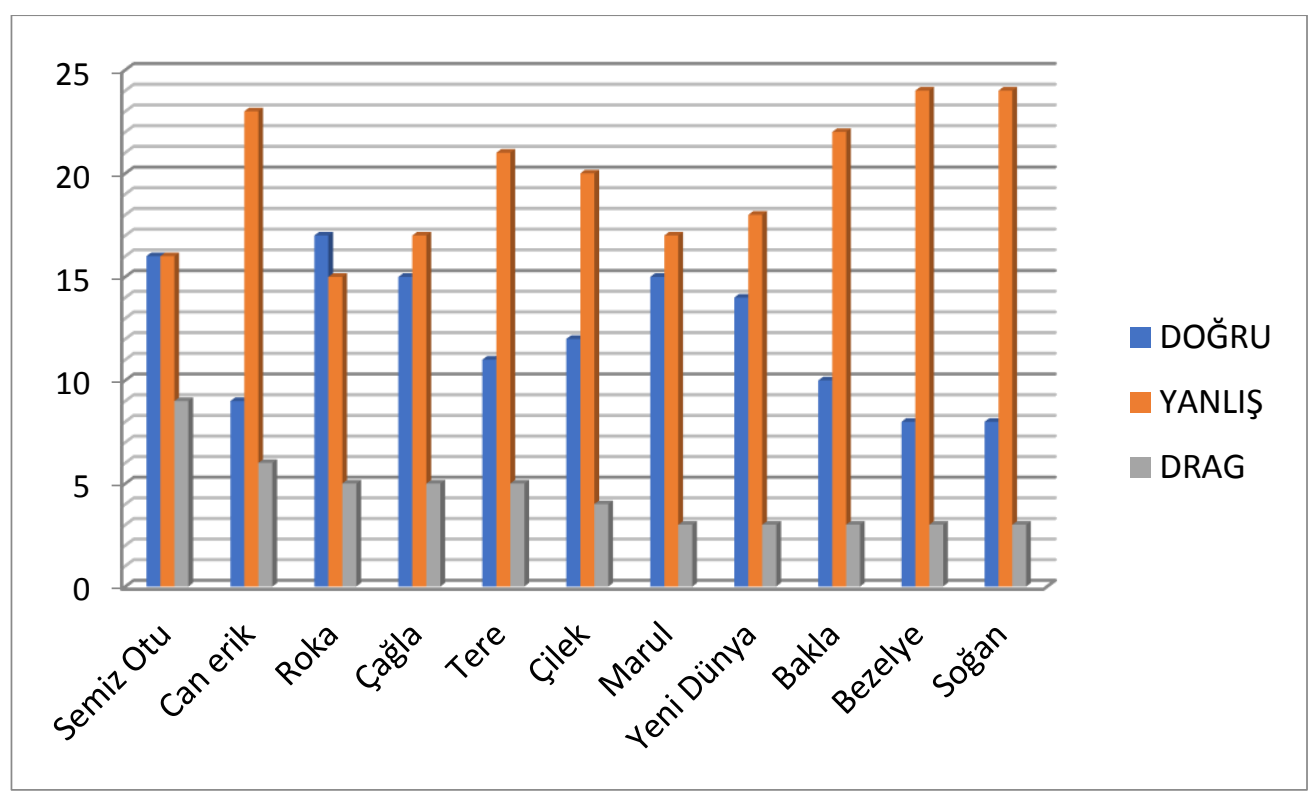

Grafik 4. Mevsimlere göre (ilkbahar) öğrencilerin meyve ve sebze seçim hareketleri

$(\mathrm{N}=32)$

Son olarak yaz mevsimi grafiği olan Grafik 5 incelendiğinde doğru cevap sayılarının yanlış cevaplara oranla daha fazla olduğu görülmektedir. Sebze ve meyve bazında incelendiğinde bu mevsimde en çok Karpuz (28), Kavun (25) ve Kayısı (21) doğru bilinmiştir. En çok yanlış bilinen üç sebze/meyve ise sırasıyla Kabak (29), Patlıcan (22) ve Biber (22)' dir. Diğer yandan "DRAG" hareketi incelendiğinde en çok Kiraz (8), Dut (6) ve Kavun (5) da sorun/kararsızlık yaşanmıştır. 


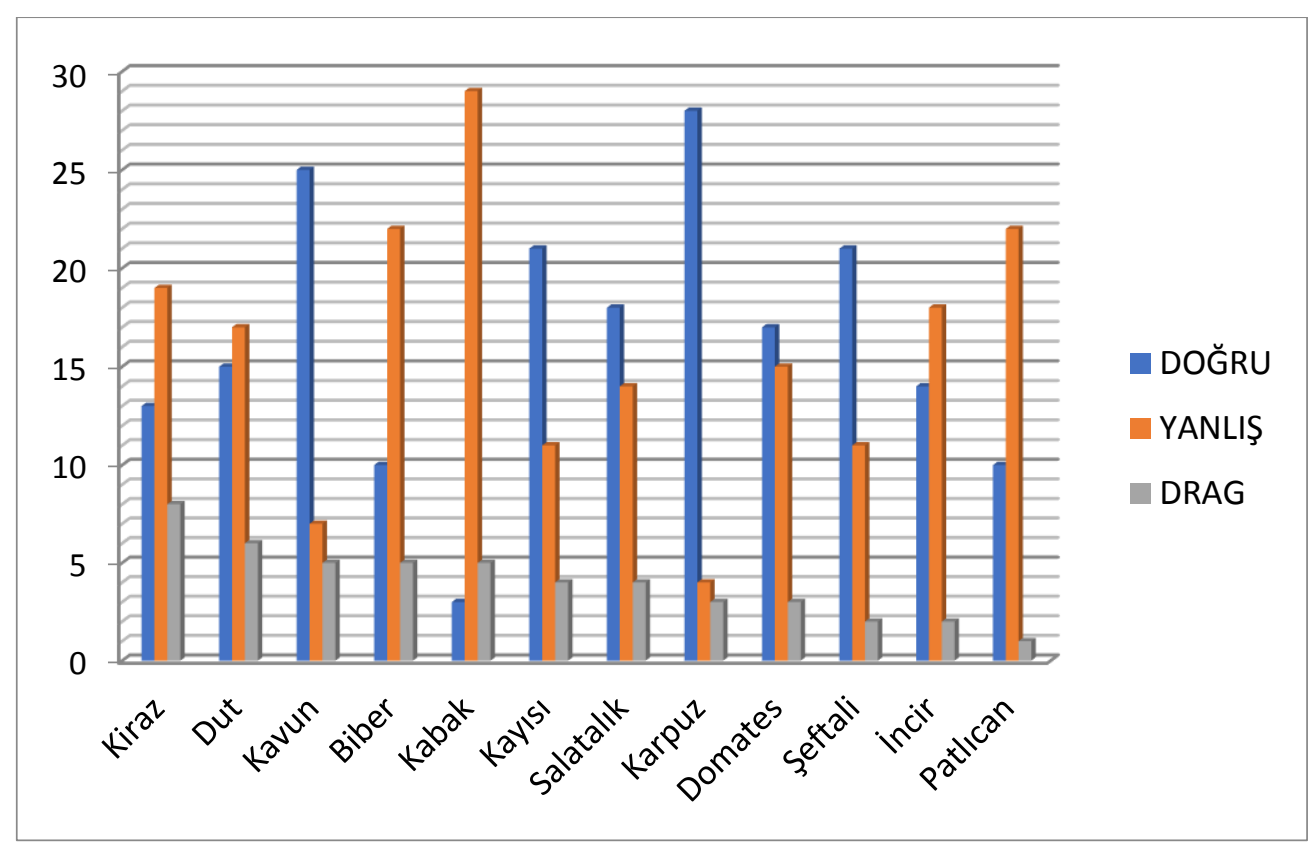

Grafik 5. Mevsimlere göre (Yaz) öğrencilerin meyve ve sebze seçim hareketleri

$(\mathrm{N}=32)$

\subsection{Değerlendirme Aracının Uygulamasına İlişkin Öğretmen Görüşleri}

Araştırmada dijital değerlendirme aracının uygulanma sürecine ilişkin öğretmen görüşleri üç tema altında toplanmıştır. Birinci temada dijital değerlendirme aracının kazanımla ilişkisi ele alınmıştır. Araştırma kapsamındaki öğretmenlerin görüşlerine göre geliştirilen dijital değerlendirme aracı Hayat Bilgisi Dersi Öğretim Programı birinci sınıf, Sağlıklı Hayat ünitesinde yer alan "1.3.8. Sağlıklı beslenme için meyve ve sebzelerin mevsimine uygun olarak tüketilmesi gerektiğini bilir" (MEB;2015) kazanımına hizmet etmektedir. Ancak kazanım günlük yaşamla örtüşmemektedir. Öğrencilerin, gerek evlerinde tüketilen meyve ve sebzeler gerekse marketlerde satılan ürünler her zaman mevsimi yansıtmamaktadır. Bu durum öğrencilerin değerlendirme sürecinde hatalar yapmalarına neden olmuştur. Bu temaya ilişkin öğretmen söylemleri şöyledir.

"Bence değerlendirme aracı olarak öğrencilerin bilgisayarda bir şeyler yapmaları çok hoşlarına gitti. Öğrencilere farklı bir şeyler sunduğunuzda dikkat toplamada hiç zorluk çekmiyorlar. Ama çok hata yapmaları meyve sebze seçiminde beni rahatsı etti. Bu değerlendirme tamamen kazanımı değerlendirmeye yönelik 
ama bazı sebzeleri tanıyamadılar özellikle evlerinde pişmiyorsa." (öğretmen 1)

"Güzel bir uygulama olmuş, biz de yeni şeyler öğreniyoruz. Kazanımı karşılıyor ama bazı sebzeler çocuklar tarafından bilinmiyor ya da muz meyvesi evinde her mevsim olabiliyor. Çocuk muzu her mevsim yiyebiliyor yani bu nedenle karıştırmaları normal diye düşünüyorum. Bezelye de örnek olabilir, anneler bezelyeyi derin dondurucuda saklıyor, kış için hazırlık yapıp derin dondurucuya bezelye koyuyor çocuk da bunu kışın yiyor. Çok kolay değil onlar için bu ayrımı yapabilmek" (öğretmen 2)

Öğretmenlerle yapılan yarı yapılandırılmış görüşmeler aracılıyla elde dilen verilerden oluşturulan ikinci tema dijital değerlendirme aracının öğrencilerin gelişim özelliklerine uygunluğu temasıdır. Bu tema kapsamında öğretmenler, araştırmada kullanılan dijital değerlendirme aracının öğrencilerin gelişim özelliklerini kısmen karşıladığı yönünde görüş bildirmişlerdir. Özellikle meyve sebzelerdeki sayının çok olduğunu bu nedenle değerlendirme süresinin uzadığını belirtmişlerdir. Ayrıca dijital değerlendirme aracı, öğrencilerin teknolojik yeterlilikleri açısından incelendiğinde, öğrencilerin fare kullanımında zorluklar yaşadıklarını dile getirmişlerdir. Bu temaya ilişkin öğretmen söylemleri şöyledir:

"Öğrenciler fare kullanmaya alışık değiller mesela bazıları ilk defa fare kullandılar. Onlar küçüklüklerinden beri daha çok akılIı telefon ve tablet kullaniyorlar. Herhalde bu nedenle fareyi kullanamadılar. Bu oyunu tablette verseydik ya da dokunma özelliği olan bir dizüstü bilgisayarda daha hızlı yaparlardı diye düşünüyorum. Bir de değerlendirme çok uzun sürüyor. Bazı sebze ve meyvelerin çıkarılması iyi olurdu. Daha fazla yaşamlarında olan meyve ve sebzeler olsa daha iyi olur." (öğretmen 1)

"Öğrencilerin, gelişim özelliklerine uygunluk açısından değerlendirdiğimde aracın kullanımında öğrencilerin teknolojik becerilerinde eksikliklerden dolayı sıkıntılar oldu. Önce fareyi kullanmayı öğretmek gerekti. Çünkü öğrencilerin bazıları fare kullanmayı bilmiyorlarmış. Öğrencilerin bu konudaki hazırbulunuşluk düzeyleri birbirinden çok farklı. Tabii ailelerin sosyoekonomik düzeyleri de burada belirleyici diye düşünüyorum. Buna benzer oyunları oynamışlar ama tablette oynamışlar. Bir de meyve ve sebze sayısı çocuklara göre çoktu. Bence meyve ve sebze sayısı azaltılmalı ve değerlendirme tablette yapılmalı. Aynı zamanda öğrenciler oyun oynarken daha rahatlar, sınıf ortamında böyle şeyler daha önce yapmadık böyle olunca hata 
İran SÜRAL | Pınar GIRMEN

yapmamak için çok düşündüler. Bu durum da uygulamanın süresini uzattı." (öğretmen 2)

Araştırmada sınıf öğretmenleriyle yapılan yarı yapılandırılmış görüşmelere dayalı olarak oluşturulan üçüncü tema dijital değerlendirme aracının geliştirilmesi için öneriler olarak belirlenmiştir. Bu temada öğretmenler, dijital değerlendirme aracında kullanılan meyve ve sebzelerin sayısının azaltılmasını, öğrencilerin dokunmatik ekranda uygulama yapmalarını, ortalama olarak daha çok öğrenciler tarafından ve onların günlük yaşamalarında olan meyve ve sebzelerin kullanılmasını dile getirmişlerdir. Aynı zamanda bu kazanımın bütün bir eğitim öğretim dönemi içine yayılarak işlenmesinin gerekliliğini de vurgulamışlardır. Bu temaya ilişkin öğretmen söylemleri şöyledir:

"Aslında çeşitlilik adına güzel oldu. Öğrenciler çok memnun kaldılar, bizlere de örnek bir uygulama oldu. Ama meyve ve sebze sayısı azalırsa daha güzel olur. Bu değerlendirmeyle ben de bu kazanımı tüm yıla yaymam gerektiğini anladım. Mesela çocuklar çağla çıkmış demek ki bahar gelmiş diye öğrencilerin dikkatini çekip onların farkına varmalarını sağlamam gerekiyor. Aslında düşününce bana da yol gösterici oldu. Teknoloji kullanımı açısından düşünürsek de fare yerine dokunmatik ekran uygulamayı daha pratik hale getirebilir. Bu tarz uygulamaların olması lazım diye düşünüyorum. Bu çocuklar dijital çağı çocukları onlara göre etkinlikler yapmak lazım. Bu uygulamayı gerekli düzeltmelerle bize bırakırsanız kullanırız." (öğretmen 1)

"Çok teşekkür ederiz ben kendi adıma güzel bir uygulama gördüm. Öğrencilerim de heyecanlandı ve mutlu oldular. Eminim eve gidince hepsi ailelerine anlatır. Yalnız sebzelerin sayısı yani meyve sebze sayısının biraz daha az olması gerekir. Bana kalırsa sayı biraz fazlaydı çocuklar küçük çok uzun sürmemesi lazım hem de tüm sebzeleri tanımıyorlar. Evde ne pişiyorsa işte. Sınıfta daha çok görsel kullanmamız lazım galiba. Öğrencilerin ekonomik durumları da bu noktada etkili oldu. Kestaneyi bilmiyor hangi mevsimde olduğunu, aslında eskiden beri derslerimizde mevsimle kestaneyi eşleştiririz ama evde yemeyince dikkat etmiyor demek ki çocuk. Teknolojik açıdan sadece fare kullanımında biraz zorlandılar, onda da zaten nasıl kullanılacağını gösterdim. Tekrar elinize sağlık." (Öğretmen 2) 


\section{Sonuç ve Öneriler}

$\mathrm{Bu}$ araştırmada, hayat bilgisi dersinde dijital bir değerlendirme aracı geliştirilmesi ve uygulama sürecinin betimlenmesine çalışılmıştır. Bu amaçla Hayat Bilgisi Dersi Öğretim Programı birinci sınıf, Sağlıklı Hayat ünitesinde yer alan "1.3.8. Sağlıklı beslenme için meyve ve sebzelerin mevsimine uygun olarak tüketilmesi gerektiğini bilir" (MEB, 2015) kazanımı seçilmiş ve bu kazanıma dayalı bir dijital değerlendirme aracı geliştirilip uygulaması gerçekleştirilmiştir. Araştırma kapsamındaki öğrenciler, mevsimlere göre meyve ve sebzeleri ayırmada başarılı olamamışlardır. Değerlendirme kapsamında kullanılan meyve ve sebzelerin bazılarının; öğrenciler tarafından hiç tüketilmemiş olması, bazılarının her mevsim evlerinde yenilebiliyor olması, bazılarınınsa sadece yemeğin içinde ve salatalarda kullanılması öğrencilerin meyve ve sebzeleri mevsimine göre ayırt etmelerinde hata yapmalarına neden olmuştur. Bu durumun bir nedenin de öğrenciler arasındaki sosyoekonomik farklılıklar olduğu düşünülebilir.

Araştırmada elde edilen sonuçlardan bir diğeri dijital değerlendirme aracında kullanılan toplam 48 meyvenin ve sebzenin nicel olarak fazla olduğudur. Bu sayı dijital değerlendirme aracının uygulama süresini çok uzatmıştır. Öğrencilerin gelişim özellikleri de dikkate alındığında bu sürenin uygun olmadığı söylenebilir. Katılımcı öğrencilerin büyük bir çoğunluğunun fare kullanma becerisinin olmaması aracın sürükle bırak eyleminde hata yapmalarına neden olmuştur. Dolayısıyla araştırma kapsamında yer alan öğrencilerin bilgisayar okuryazarlıklarının farklılık gösterdiği sonucuna ulaşılmıştır.

Hayat bilgisi dersi çocukların temel yaşam becerilerini edinmelerini ve edindikleri bilgi ve becerileri kendi yaşamlarına aktarmalarını hedefleyen ilkokul düzeyindeki ilk derstir. Bu rolüyle öğrencilerin bu bilgi ve becerileri yaşamlarında nasıl kullandıklarının belirlenmesi oldukça önemlidir. Araştırmada elde edilen veriler bu bağlamda ele alındığında ilgili kazanımın çocuklara edindirilmesi konusunda çok başarılı olunamadığı sonucuna ulaşımıştır. Çocukların meyve ve sebzeleri tanımada aile çevrelerinin okula göre daha etkili olduğu görülmektedir. Dolayısıyla öğrencilerin aile ve sosyal çevrelerindeki yaşamları okul yaşantısının üzerinde olduğu söylenebilir.

Ulaşılan sonuçlar doğrultusunda aşağıdaki öneriler geliştirilmiştir.

- İlkokul düzeyinde oluşturulacak dijital değerlendirme araçlarının geliştirilmesinde uygulama süresine dikkat edilmelidir.

- Dijital değerlendirme araçları geliştirilirken hedef kitlenin bilgisayar okuryazarlıkları ve sosyoekonomik düzeylerine dayalı olarak teknolojiye erişim durumları göz önünde bulundurulmalıdır.

- Öğretim programlarındaki sık değişimler araştırma kapsamında ele alınan Hayat Bilgisi Dersi Öğretim Programı birinci sınıf, Sağııkı Hayat ünitesinde yer alan "1.3.8. Sağlıklı beslenme için meyve ve sebzelerin mevsimine uygun olarak tüketilmesi gerektiğini bilir" (MEB, 2015) kazanımı 2018 Hayat Bilgisi Dersi Öğretim Programı’nda birinci 
İrfan SÜRAL | Pınar GIRMEN

sınıf düzeyinde yer almamaktadır. Bu kazanımla örtüşen "HB.2.3.6. mevsimine uygun meyve ve sebze tüketiminin insan sağlığına etkilerini fark eder ve HB.3.3.3. sağlığını korumak için mevsimlere özgü yiyeceklerle beslenir." (MEB, 2018) kazanımları ilkokul ikinci ve üçüncü sınıflarda sağlıklı hayat ünitesine yer almaktadır. Bu bağlamda geliştirilen dijital değerlendirme aracı farklı sınıf düzeylerinde kullanılabilir.

- Dijital değerlendirme ortamlarında özellikle ilkokul düzeyinde sürükle bırak ögelerinin sayısına dikkat edilmelidir. Geliştirilen dijital değerlendirme aracı kapsamı düşünüldüğünde daha az meyve ve sebze kullanılmalıdır.

- Öğrenciler geliştirilen dijital değerlendirme aracını kullanırken keyif almışlardır. Bu nedenle sadece değerlendirme süreçlerinde değil öğrenme süreçlerinin her aşamasında teknoloji destekli etkinliklere yer verilmelidir.

- Araştırma kapsamında ele alınan kazanımın tüm yıl boyunca somut etkinliklerle işlenmesi konunun kalıcılığı açısından önemlidir.

\section{Kaynaklar}

Akça, M. A., Barut, E., ve Önder, R. (2014). Fen Bilgisi Eğitimi için Web Tabanlı Öğrenme Ortamı. International Conference on Education in Mathematics, Science and Technology (s. 190-196). Konya: Necmettin Erbakan Üniversitesi.

An, Y.-J., Aworuwa, B., Ballard, G., ve Williams, K. (2010). Teaching with Web 2.0 Technologies: Benefits, Barriers and Best Practices. International Journal of Instructional Technology and Distance Learning, 7, 41-48.

Anılan, H., ve Kılıç, Z. (2010). Hayat bilgisi dersinde kullanılan performans değerlendirmeye ilişkin öğretmen görüşleri. e-Journal of New World Sciences Academy, 5(3), 1356-1369.

Baki, A., ve Gökçek, T. (2012). Karma Yöntem Araştırmalarına Genel Bir Bakış. Elektronik Sosyal Bilimler Dergisi, 11(42), 1-21.

Creswell, J. W. (2008). Educational research: planning, conducting and evaluating quantitaive and qualitative research (3. ed.). New Jersey: Pearson Education, Inc. Upper Saddle River.

Çetinkaya, M., ve Taş, E. (2016). Web Destekli ve Etkinlik Temelli Ölçme Değerlendirme Materyali Geliştirilmesi. Eğitim ve Öğretim Araştırmaları Dergisi, 5(1), 21-28. 
Duban, N., ve Küçükyılmaz, E. A. (2008). Sınıf öğretmeni adaylarının alternatif ölçme değerlendirme yöntem ve tekniklerinin uygulama okullarında kullanımına ilişkin görüşleri. ilköğretim Online, 7(3), 769-784.

Eyal, L. (2012). Digital Assessment Literacy - the Core Role of the Teacher in a Digital Environment. International Forum of Educational Technology \& Society, 15(2), 37-49.

Gay, L. R., Mills, G. E., ve Airasian, P. W. (2006). Educational research: competencies for analysis and applications (8. Baskı b.). New Jersey: Pearson Education.

Gömleksiz, M. N., Yıldırım, F., ve Yetkiner, A. (2011). Hayat bilgisi dersinde alternatif ölçme değerlendirme tekniklerinin kullanımına ilişkin öğretmen görüşleri. e-Journal of New World Sciences Academy, 823-840.

Güleryüz, H. (2008). Hayat Bilgisi Öğretimi ve Programı. Pegem Akademi Yayıncılık.

Güneş, T., Dilek, N. Ş., Hoplan, M., Çelikoğlu, M., ve Demir, E. S. (2010). Teachers' opinions on alternative assessment and their applications. International Conference on New Trends in Education and Their Implications, 925-935.

Johnson, B., \& Christensen, L. (2008). Educational research: quantitative, qualitative and mixed approaches (3. ed.). California: SAGE.

Johnson, R. B., ve Onwuegbuzie, A. J. (2004). Mixed Methods Research:A Research Paradigm Whose Time Has Come. Educational Researcher, 33(7), 14-26. 11 20, 2018 tarihinde http://www.aera.net/uploadedfiles/journals_and_publications/journals/educational _researcher/volume_33_no_7/03erv33n7_johnson.pdf adresinden alındı

Kabapınar, Y. (2012). Kuramdan Uygulamaya Hayat Bilgisi ve Sosyal Bilgiler Öğretimi (Geliştirilmiş 3. b.). Ankara: Pegem Akademi Yayıncılık.

Kanatlı, F. (2008). Alternatif ölçme ve değerlendirme teknikleri konusunda sınıf öğretmenlerinin görüşlerinin değerlendirilmesi. Yayınlanmamış yüksek lisans tezi. Hatay: Mustafa Kemal Üniversitesi Sosyal Bilimler Enstitüsü.

Karamustafaoğlu, S., Çağlak, A., ve Meşeci, B. (2012). Alternatif ölçme değerlendirme araçlarına ilişkin sınıf öğretmenlerinin öz yeterlilikleri. Amasya Üniversitesi Eğitim Fakültesi Dergisi, 1(2), 167-179. 
Kaya, A., Balay, R., ve Göçen, A. (2012). Öğretmenlerin alternatif ölçme ve değerlendirme tekniklerine ilişkin bilme, uygulama ve eğitim ihtiyacı düzeyleri. International Journal of Human Sciences, 9(2), 1229- 1259.

Kilmen, S., ve Kösterelioğlu, i. (2017). Öğretmenlerin tamamlayıcı değerlendirme yaklaşımlarına yönelik görüşlerinin CHAID analizi ile incelenmesi. Ilköğretim Online, 16(1), 256-273.

MEB. (2015). Hayat bilgisi dersi öğretim programı (ilkokul 1,2 ve 3.sınıflar). Ankara: Milli Eğitim Bakanlığı Yayınları.

MEB. (2018). Hayat bilgisi dersi öğretim programı (ilkokul 1,2 ve 3.sınıflar). Ankara: Milli Eğitim Bakanlığı Yayınları.

Ören, F. Ş., Ormancı, Ü., ve Evrekli, E. (2014). Öğretmen Adaylarının Tercih Ettikleri Alternatif Ölçme-Değerlendirme Yaklaşımları ile Bu Yaklaşımlara illişkin ÖzYeterlilikleri. Eğitim ve Bilim, 39(173), 101-116.

Paliç, G., ve Akdeniz, A. R. (2012). Beyin Temelli Öğrenmeye Dayalı Web Destekli Bir Öğretim Materyalinin Tasarlanması ve Değerlendirilmesi. Necatibey Eğitim Fakültesi Elektronik Fen ve Matematik Eğitimi Dergisi (EFMED), 6(1), 67-93.

Prensky, M. (2007). Digital game-based learning. St. Paul: Paragon House Ed .

Yıldırım, A., ve Şimşek, H. (2013). Sosyal Bilimlerde Nitel Araştırma Yöntemleri. Ankara: Seçkin Yayıncılık. 